\author{
Aleksandra Sikorska-Lewandowska \\ Uniwersytet Mikołaja Kopernika, Toruń \\ as1@umk.pl \\ ORCID: https://orcid.org/0000-0002-3234-2502
}

\title{
Odpowiedzialność odszkodowawcza członka zarządu wspólnoty mieszkaniowej
}

\author{
http://dx.doi.org/10.12775/SIT.2019.011
}

\begin{abstract}
Wspólnota mieszkaniowa uznawana jest w doktrynie oraz w orzecznictwie $^{1}$ za jednostkę organizacyjną, której ustawa przyznaje zdolność prawną, a więc w świetle art. 331 kodeksu cywilnego ${ }^{2}$ należy ona do kategorii ułomnych osób prawnych. Ogół właścicieli lokali danej nieruchomości tworzy z mocy prawa wspólnotę mieszkaniową. Przepisy rozdziału 4 ustawy o własności lokali ${ }^{3}$ przewidują możliwość umownej regulacji zasad zarządu nieruchomością wspólną, a w przypadku braku takiej umowy dla dużych ${ }^{4}$ wspólnot mieszkaniowych przewidziany został w art. 20 u.w.1. obowiązek powołania zarządu.
\end{abstract}

${ }^{1}$ Uchwała SN (7) z dnia 21 grudnia 2007 r., III CZP 65/07, OSNC 2008, nr 7-8, poz. 69 .

${ }^{2}$ Ustawa z dnia 23 kwietnia 1964 r. Kodeks cywilny (tekst jednolity: Dz.U. z 2017 r. poz. 459 ze zm.; dalej: k.c.).

${ }^{3}$ Ustawa $z$ dnia 24 czerwca 1994 r. o własności lokali (tekst jednolity: Dz.U. z 2018 r. poz. 716; dalej: u.w.1.).

${ }^{4}$ Duża wspólnota mieszkaniowa zgodnie z art. 19 i 20 u.w.1. liczy więcej niż 7 lokali. 
Większość doktryny uznaje zarząd za organ wspólnoty mieszkaniowej ${ }^{5}$. Uprawnienie zarządu do działania za wspólnotę mieszkaniową wynika $z$ przepisów ustawy o własności lokali, nie zaś z woli podmiotu reprezentowanego wyrażonej osobnym oświadczeniem ${ }^{6}$. Zarząd został określony w orzecznictwie jako organ wykonawczy ułomnej osoby prawnej, jaką jest wspólnota mieszkaniowa ${ }^{7}$. Z mocy art. 331 § 1 k.c. do osób ustawowych zastosowanie znajdują odpowiednio przepisy o osobach prawnych. Zgodnie $z$ teorią organów, uznawaną za obowiązującą $\mathrm{w}$ prawie cywilnym, działanie organu jest działaniem samej osoby prawnej ${ }^{8}$.

W związku z funkcjonowaniem określonej osoby fizycznej w ramach organu, czyli zarządu wspólnoty, należy rozważyć, jakie są reguły odpowiedzialności cywilnoprawnej takiej osoby za szkody wyrządzone przy wykonywaniu czynności związanych $z$ obowiązkami członka zarządu. W piśmiennictwie brakuje szerszych wypowiedzi dotyczących tej tematyki, także w orzecznictwie sądów jest to zagadnienie rzadko poruszane. Konieczne jest rozważenie, jakie są przesłanki odpowiedzialności odszkodowawczej oraz jaka może być podstawa prawna roszczeń wspólnoty mieszkaniowej wobec członka zarządu. Punktem wyjścia dla dalszych rozważań powinno być określenie statusu prawnego członka zarządu wspólnoty mieszkaniowej.

${ }^{5}$ A. Turlej, w: R. Strzelczyk, A. Turlej, Własność lokali, komentarz, Warszawa 2015, s. 516; M. Szewczyk, Reprezentacja wspólnoty mieszkaniowej, „Radca Prawny" 2001, nr 1, s. 74; J. Kozińska, Status prawny zarzadu wspólnoty mieszkaniowej - zagadnienia wybrane, „Rejent” 2003, nr 12, s. 121; P. Skibiński, Reprezentacja wspólnoty mieszkaniowej na gruncie ustawy o własności lokali, „Przegląd Sądowy” 2007, nr 5, s. 85.

${ }^{6}$ J. Kozińska, Status, s. 122.

7 Postanowienie SA w Poznaniu z dnia 5 lutego 2014 r., I ACz 133/14, Lex nr 1428207.

${ }^{8}$ K.A. Dadańska, Działanie osoby prawnej, Warszawa 2006, s. 30. 


\section{Stosunek członkostwa w zarządzie wspólnoty mieszkaniowej}

Członek zarządu zostaje wybrany na podstawie art. 20 ust. 1 u.w.1. w drodze uchwały podjętej przez właścicieli lokali ${ }^{9}$. Ustawodawca wymaga, aby była to osoba fizyczna, ale nie musi być właścicielem lokalu. Wskutek wyboru w skład zarządu osoba fizyczna staje się piastunem organu, przyjmuje więc na siebie pełnienie obowiązków związanych $z$ tą funkcją. Odpowiedzialność cywilnoprawną członka zarządu należy więc łączyć z niewykonaniem lub nienależytym wykonaniem tych obowiązków. Do podstawowych obowiązków członka zarządu należy zaliczyć: reprezentowanie wspólnoty na zewnątrz i pomiędzy wspólnotą a poszczególnymi właścicielami lokali oraz prowadzenie spraw wspólnoty: w zakresie nieprzekraczającym zwykłego zarządu - samodzielnie lub z innymi członkami zarządu, w zakresie przekraczającym zakres zwykłego zarządu - na podstawie podjętych uchwał, wykonując zawarte w nich postanowienia. Członek zarządu powinien działać w interesie wspólnoty mieszkaniowej, tak aby jego poczynania nie przyniosły jej szkody. Z brzmienia art. 26 u.w.1. można wywieść obowiązek przestrzegania zasad prawidłowej gospodarki; za podstawowe zadanie zarządu należy uznać zapewnienie należytego stanu nieruchomości wspólnej. Ustawa precyzuje niektóre obowiązki zarządu, takie jak zwoływanie corocznych zebrań właścicieli lokali (art. 30 ust. 1 pkt 3 u.w.1.), prowadzenia dokumentacji finansowej nieruchomości wspólnej (art. 29 ust. 1 u.w.1.), dokumentacji technicznej (art. 29 ust. $1 \mathrm{~b}$ u.w.1.) oraz składania rocznego sprawozdania ze swej działalności (art. 30 ust. 1 pkt 2 u.w.l).

Należy przyjąć, że członek zarządu ponosi odpowiedzialność względem wspólnoty mieszkaniowej, a więc wobec ogółu właścicieli lokali w tej nieruchomości, za szkodę wyrządzoną przy wykonywaniu tych ustawowo określonych obowiązków.

9 Por. A. Sikorska-Lewandowska, Uchwały właścicieli lokali. Studium prawne, Warszawa 2017. 
Przepisy ustawy o własności lokali nie zawierają szczegółowej regulacji w zakresie statusu prawnego członka zarządu, jak również odpowiedzialności członków zarządu za szkodę wyrządzoną wspólnocie mieszkaniowej. W tej sytuacji, zgodnie $z$ art. 1 ust. 2 u.w.l. w zakresie nieuregulowanym ustawą, do własności lokali stosuje się przepisy kodeksu cywilnego. Podobny wniosek wynika $z$ art. 331 $\S 1$ k.c. odsyłającego do odpowiedniego stosowania przepisów o osobach prawnych.

Wybór do składu zarządu inicjuje stosunek organizacyjny (korporacyjny) pomiędzy powołaną osobą a wspólnotą mieszkaniową, na podstawie którego dana osoba zyskuje status członka zarządu i realizuje związane $z$ nim prawa i obowiązki. W piśmiennictwie dotyczącym wspólnot mieszkaniowych wypowiedzi na temat charakteru prawnego stosunku członkostwa w zarządzie wspólnoty mieszkaniowej są nieliczne. Przywołać należy stwierdzenie, że stosunek prawny wynikający $z$ powołania uchwałą jest inny niż stosunek prawny, jaki może łączyć wspólnotę z członkiem zarządu wskutek zawarcia umowy o pracę lub umowy zlecenia ${ }^{10}$. Wybór na członka zarządu na ogół nie wiąże się z nawiązaniem pomiędzy wspólnotą a członkami zarządu stosunku pracy czy zlecenia. Przeważnie zarządy wspólnot mieszkaniowych przybierają formę zarządów społecznych, które nie pobierają $z$ tego tytułu żadnych uposażeń ${ }^{11}$. Stosunek organizacyjny łączący piastuna organu ze wspólnotą jest postrzegany w niektórych wypowiedziach doktryny jako stosunek cywilnoprawny. Przyjmuje się, że do stosunku członkostwa w zarządzie, w zakresie nieuregulowanym w ustawie, mają zastosowanie przepisy prawa cywilnego dotyczące zlecenia, niezależnie od praw i obowiązków wynikających z umowy (uchwały o powołaniu) ${ }^{12}$. Do relacji między członkami zarządu wspólnoty a samą wspólnotą stosuje się przepisy prawa cywilnego, zwłaszcza

10 J. Pisuliński, w: System Prawa Prywatnego, t. 3: Prawo rzeczowe, red. Z. Radwański, Warszawa 2013, s. 821.

11 A. Turlej, Własność, s. 670.

${ }^{12}$ R. Dziczek, Własność lokali. Komentarz. Wzory pozwów i wniosków, Warszawa 2012, s. 186. 
dotyczące zlecenia (art. 750 k.c.), gdyż stosunek członkostwa ma charakter cywilnoprawny ${ }^{13}$.

Zagadnienie charakteru prawnego stosunku organizacyjnego jest przedmiotem szerszych wypowiedzi w doktrynie prawa cywilnego oraz prawa handlowego, zwłaszcza w odniesieniu do spółek kapitałowych. Stosunki korporacyjne, rozumiane jako stosunki łączące członków, osobę prawną, organy oraz ich piastunów są postrzegane jako specyficzne stosunki cywilnoprawne ${ }^{14}$. Przyjmuje się, że pomimo braku wyraźnego odesłania w kodeksie spółek handlowych ${ }^{15}$ do stosunku pomiędzy spółką a członkami organu należy stosować przepisy kodeksu cywilnego o odnoszące się do zlecenia ${ }^{16}$. Ich źródłem są umowy spółek, jednostronne czynności prawne w postaci aktów założycielskich lub przepis ustawy, który powołuje do życia jednostkę organizacyjną oraz wyposaża ją w osobowość prawną ${ }^{17}$. W przypadku wspólnot mieszkaniowych należy uznać, że pomiędzy nimi jako ułomnymi osobami prawnymi a członkami ich zarządów występują także stosunki korporacyjne, które nie zostały uregulowane wprost w ustawie o własności lokali, lecz mają charakter cywilnoprawny. Ich źródłem jest bowiem stosunek współwłasności nieruchomości wspólnej zawiązany pomiędzy członkami wspólnoty mieszkaniowej oraz uchwała jako czynność prawna o charakterze kreującym.

W doktrynie prawa handlowego prezentowane są także odmienne poglądy, zgodnie z którymi mandat członka zarządu spółki z o.o. jest stosunkiem prawnym o charakterze korporacyjnym (regulowanym przez prawo spółek - art. 202 k.s.h.), który powstaje pomiędzy tym członkiem zarządu a spółką. Odróżnia się go od innego stosunku prawnego, tj. o charakterze kontraktowym (regulowanym przez prawo zobowiązań), który przyjmuje postać umowy o pracę bądź

\footnotetext{
13 A. Turlej, Własność, s. 530.

${ }^{14}$ Z. Banaszczyk, w: System Prawa Prywatnego, t. I, red. M. Safjan, Warszawa 2012, s. 977.

${ }^{15}$ Ustawa z dnia 15 września 2000 r. - Kodeks spółek handlowych (tekst jednolity: Dz.U. z 2017 r. poz. 1577, dalej: k.s.h.)

${ }^{16}$ A. Rachwał, w: System Prawa Handlowego. t. 2B: Prawo Spółek Handlowych, red. S. Włodyka, Warszawa 2007, s. 783.

17 Z. Banaszczyk, op.cit., s. 980.
} 
umowy zlecenia czy świadczenia usług albo umowy nienazwanej w postaci kontraktu menedżerskiego ${ }^{18}$.

W odniesieniu do wspólnot mieszkaniowych należy przyjąć, że stosunek organizacyjny łączący członka zarządu $z$ tą jednostką organizacyjną ma charakter cywilnoprawny. Stosunki współwłasności łączące właścicieli lokali we wspólnocie mieszkaniowej mają charakter cywilnoprawny, co wynika $z$ art. 1 ust. 2 u.w.l. zawierającego odesłanie do stosowania wprost przepisów kodeksu cywilnego. Więzi pomiędzy współwłaścicielami o charakterze prawnorzeczowym są również rodzajem stosunku cywilnoprawnego, tak samo jak więź organizacyjna powstała za sprawą powołania w skład zarządu określonej osoby, niezależnie od tego, czy jest to jeden z właścicieli czy osoba trzecia. Powołanie takie wymaga zgody tej osoby, a więc złożenia stosownego oświadczenia woli, co skutkuje nawiązaniem relacji o charakterze cywilnoprawnym. Cechą charakterystyczną tej więzi jest możliwość jej zerwania w każdej chwili - zarówno członek zarządu może być w każdej chwili odwołany bez podawania przyczyny, jak i może zrezygnować ze sprawowania tej funkcji.

Rozważania w przedmiocie odpowiedzialności odszkodowawczej będą dotyczyły osoby fizycznej powołanej w skład zarządu spośród właścicieli lokali (lub spoza tego grona) nieposiadających kwalifikacji zarządcy, pełniącej funkcję członka zarządu społecznie. Przedmiotem analizy będzie typowa sytuacja, gdy dokonuje się jedynie wyboru określonej osoby do zarządu wspólnoty mieszkaniowej, z którą wspólnota nie zawiera jakiejkolwiek umowy dotyczącej sprawowania funkcji członka zarządu.

\section{Podstawa oraz przesłanki odpowiedzialności cywilnoprawnej}

Wspólnota mieszkaniowa jako podmiot prawa wyposażony w zdolność prawną może być poszkodowana wskutek działań lub zaniechań innego podmiotu, w tym również członka swojego organu.

${ }^{18}$ A. Szumański, w: System Prawa Prywatnego, t. 17A: Prawo Spółek Kapitałowych, red. S. Sołtysiński, Warszawa 2015, s. 526. 
Wobec braku szczególnej regulacji odnoszącej się do zasad odpowiedzialności członka zarządu wspólnoty mieszkaniowej w ustawie o własności lokali zgodnie z przepisem art. 1 ust. 2 u.w.l. stosuje się przepisy kodeksu cywilnego. W pierwszej kolejności należy stwierdzić, jaki reżim odpowiedzialności odszkodowawczej może mieć zastosowanie w przypadku wyrządzenia wspólnocie mieszkaniowej szkody przez członka jej zarządu, następnie - jakie są przesłanki oraz podstawy odpowiedzialności.

\subsection{Odpowiedzialność deliktowa członka zarządu wspólnoty mieszkaniowej}

Członek zarządu w przypadku wyrządzenia wspólnocie mieszkaniowej szkody czynem niedozwolonym będzie ponosił odpowiedzialność ex delicto na takich samych zasadach jak każda inna osoba.

Odpowiedzialność na podstawie art. 415 k.c. jest oparta na zasadzie winy, a ciężar udowodnienia zaistnienia tej podstawy odpowiedzialności spoczywa na podmiocie, który poniósł szkodę. Wspólnota musi wykazać, że poniosła szkodę wskutek popełnienia przez członka zarządu czynu niedozwolonego, a także to, że wystąpił związek przyczynowy pomiędzy szkodą a czynem niedozwolonym oraz udowodnić zaistnienie podstawy odpowiedzialności, a więc winy.

Na podstawie przepisu art. 415 k.c. odpowiedzialność odszkodowawczą ponosi każdy, kto $z$ winy swojej wyrządzi drugiemu szkodę. Wspólnota mieszkaniowa jako ułomna osoba prawna zgodnie z przepisem art. 6 u.w.l. jest podmiotem praw i obowiązków, a więc może jej zostać wyrządzona szkoda. Skoro każdy może szkodę wyrządzić, to może to zrobić również członek zarządu wspólnoty, ale także każdy z właścicieli lokali oraz osoba trzecia; próba formułowania katalogu podmiotów ponoszących odpowiedzialność na podstawie art. 415 k.c. wydaje się bezcelowa wobec jednoznacznego użycia przez ustawodawcę słowa „każdy”.

Nieliczne wypowiedzi przedstawicieli doktryny poświęcone zagadnieniu odpowiedzialności członków zarządu wspólnoty mieszkaniowej wskazują właśnie na przepis art. 415 k.c. jako podstawę 
odpowiedzialności odszkodowawczej członka zarządu względem wspólnoty mieszkaniowej ${ }^{19}$. Przedstawione poglądy doktryny nawiązują do uzasadnienia uchwały ${ }^{20}$ Sądu Najwyższego, w którym zaprezentowano stanowisko wskazujące na to, że członkowie zarządu za szkodę wyrządzoną wspólnocie ponoszą odpowiedzialność deliktową, w przeciwieństwie do zarządcy, który odpowiada na podstawie art. 471 k.c. Ten pogląd, zawarty w uzasadnieniu uchwały, nie został szerzej uargumentowany, zgodzić się należy z tym fragmentem, w którym wskazano, że członkowie zarządu mogą na podstawie art. 429 k.c. ponosić odpowiedzialność za winę w wyborze zarządcy.

Jak się wydaje, zarówno przedstawiciele doktryny, jak i Sąd Najwyższy w przytoczonej uchwale zdają się przeciwstawiać odpowiedzialność kontraktową profesjonalnego zarządcy (w rozumieniu przepisu art. 184a ustawy o gospodarce nieruchomościami)21 odpowiedzialności niebędących profesjonalistami członków zarządu wspólnoty mieszkaniowej. W efekcie przyjmowana jest konkluzja, zgodnie z którą „zwykli” członkowie zarządu ponoszą odpowiedzialność odszkodowawczą jedynie w przypadku wyrządzenia szkody czynem niedozwolonym, a profesjonalny zarządca ponosi odpowiedzialność także na podstawie kontraktowej. Takie stanowisko wydaje się zbyt dużym uproszczeniem, w mojej bowiem ocenie zróżnicowanie charakteru odpowiedzialności członków zarządu oraz profesjonalnego zarządcy powinno występować, owszem, lecz kryterium dyferencjacji powinna stanowić wyłącznie miara staranności. Ponadto niekiedy zarządy samodzielnie prowadzą sprawy wspólnoty, nie zawierając umów o administrowanie $z$ profesjonalnymi podmiotami.

19 J. Kozińska, Środki kontroli działalności zarządu lub zarządcy według ustawy o wtasności lokali, „Studia Prawnicze” 2013, nr 2(57), s. 138; I. Szymczak, Wspólnota mieszkaniowa, Warszawa 2014, s. 202.

${ }^{20}$ Uchwała SN z dnia 16 lutego 2012 r., III CZP 96/11, OSNC 2012 nr 7-8, poz. 88.

${ }^{21}$ Ustawa $z$ dnia 21 sierpnia 1997 r. o gospodarce nieruchomościami (Dz.U. z 2018 r. poz. 121 ze zm.). 


\subsection{Odpowiedzialność kontraktowa członka zarządu wspólnoty mieszkaniowej}

Przyjęcie założenia, zgodnie $z$ którym wskutek powołania określonej osoby do składu organu wspólnoty mieszkaniowej nawiązuje się stosunek organizacyjny o charakterze cywilnoprawnym, implikuje tezę o kontraktowej podstawie odpowiedzialności piastuna organu. $\mathrm{W}$ efekcie stosowania bowiem przepisów o zleceniu, nawet w sytuacji braku odrębnej umowy, znajdzie zastosowanie art. 471 k.c. statuujący odpowiedzialność ex contractu. Niezależnie od tego, w przypadku wyrządzenia przez członka zarządu wspólnocie szkody czynem niedozwolonym, podstawą jego odpowiedzialności będzie art. 415 k.c. W piśmiennictwie brakuje szerszych wypowiedzi na temat odpowiedzialności ex contractu w przypadku pełnienia funkcji członka zarządu tylko na podstawie powołania uchwałą podjętą przez właścicieli lokali. Jedynie Jerzy Ignatowicz w jednoznaczny sposób stwierdza, że członek zarządu wspólnoty mieszkaniowej ponosi odpowiedzialność za szkody wyrządzone spółce na podstawie kontraktowej22. Pogląd ten został sformułowany na tle wykładni art. 27 u.w.1. i odnosi się do wszystkich członków wspólnoty mieszkaniowej, jak również członków jej zarządu - jego autor uznaje tym samym ten przepis za źródło wzajemnych zobowiązań właścicieli lokali. Stanowisko to zasługuje na aprobatę, w szczególności jeśli chodzi o odpowiedzialność członków zarządu wspólnoty za wyrządzoną jej szkodę. Jak wskazano wyżej, z powierzeniem pełnienia funkcji członka zarządu łączy się szereg określonych w ustawie obowiązków oraz uprawnienie do podejmowania decyzji w zakresie zwykłego zarządu. Trudno przyjąć, aby ta szczególna pozycja w strukturze wspólnoty, a więc członkostwo w jej zarządzie, nie miała łączyć się z odpowiedzialnością kontraktową za niewykonanie lub nienależyte wykonanie zobowiązań, które wynikają z przepisów ustawy lub uchwał podjętych przez właścicieli lokali. Przeciwny pogląd - zgodnie z którym członek zarządu wspólnoty miałby ponosić

\footnotetext{
22 J. Ignatowicz, Komentarz do ustawy o własności lokali, Warszawa 1995, s. 94 .
} 
odpowiedzialność jedynie w przypadku wyrządzenia szkody czynem niedozwolonym - zrównuje pozycję członka zarządu $z$ każdym innym podmiotem, który wyrządził wspólnocie szkodę. Z taką interpretacją nie można się zgodzić, ponieważ jest ona niekorzystna dla wspólnot mieszkaniowych i prowadzi do uznania, że pełnienie funkcji członka zarządu wspólnoty mieszkaniowej nie jest powiązane $z$ jakąkolwiek odpowiedzialnością cywilnoprawną.

Zgodnie $\mathrm{z}$ art. 471 k.c. dłużnik ponosi odpowiedzialność za szkodę wywołaną wskutek niewykonania lub nienależytego wykonania zobowiązania, chyba że niewykonanie lub nienależyte wykonanie jest następstwem okoliczności, za które nie ponosi on odpowiedzialności. Podstawową kategorią odpowiedzialności kontraktowej jest więc pojęcie niewykonania lub nienależytego wykonania zobowiązania. W doktrynie podkreślono, że źródło zobowiązania, które nie zostało wykonane lub zostało wykonane nienależycie, należy rozumieć szeroko, zalicza się tu m.in. zobowiązania wynikające ze stosunków uregulowanych w innych niż prawo zobowiązań działów prawa, np. prawa rzeczowego ${ }^{23}$. W przypadku sprawowania funkcji członka zarządu wspólnoty mieszkaniowej wyłącznie na podstawie powołania w drodze uchwały, katalog obowiązków piastuna tego organu może zostać określony jedynie na podstawie przepisów ustawy o własności lokali oraz zasad współżycia społecznego i zwyczajów. W związku z tym, że uchwała właścicieli lokali o powołaniu określonej osoby w skład zarządu jest czynnością prawną ${ }^{24}$, wywołuje ona zgodnie $z$ art. 56 k.c. nie tylko skutki w niej wyrażone, lecz także te, które wynikają $z$ ustawy, $z$ zasad współżycia społecznego i ustalonych zwyczajów. Łącznie kreują one treść stosunku prawnego. O cywilnoprawnym charakterze stosunku korporacyjnego świadczy również to, że osoba powołana w skład zarządu musi wyrazić zgodę na pełnienie tej funkcji, a więc składa stosowne oświadczenie woli, które obejmuje akceptację obowiązków wynikających $\mathrm{z}$ ustawy. W istocie nawiązanie stosunku członkostwa następuje wskutek złożenia oświadczenia woli przez wspólnotę,

${ }^{23}$ M. Kaliński, Szkoda na mieniu i jej naprawienie, Warszawa 2011, s. 29.

24 A. Sikorska-Lewandowska, Charakter prawny uchwał wtaścicieli lokali, „Przegląd Sądowy” 2014, nr 6, s. 101. 
w drodze uchwały oraz przez osobę wybraną w skład zarządu poprzez zgodę na ten wybór i sprawowanie przydzielonej funkcji. Powierzenie w drodze umowy przez członków zarządu wykonywania czynności zarządzania profesjonalnemu zarządcy będzie co do zasady zwalniało członków zarządu od odpowiedzialności, gdyż to profesjonalista będzie podmiotem zobowiązanym do prawidłowego działania w interesie wspólnoty mieszkaniowej.

Przepis art. 471 k.c. wyraźnie łączy odpowiedzialność dłużnika z uchybieniem obowiązkowi na skutek takich okoliczności, za które ponosi on odpowiedzialność. Po stronie członka zarządu pozostaje więc wykazanie, że za określone okoliczności, wskutek których doszło do niewykonania lub nienależytego wykonania zobowiązania, nie ponosi on odpowiedzialności. Jednocześnie musi wykazać, że zachował przy wykonywaniu swych obowiązków należytą staranność, zgodnie $z$ art. 472 k.c.

Pozostałymi przesłankami odpowiedzialności ex contractu jest poniesienie szkody oraz wykazanie związku przyczynowego pomiędzy niewykonaniem lub nienależytym wykonaniem zobowiązania przez członka zarządu a szkodą poniesioną przez wspólnotę mieszkaniową. W tym zakresie ciężar dowodu spoczywa na wspólnocie mieszkaniowej.

\subsection{Szkoda oraz związek przyczynowy}

Przepisy prawa określają przesłanki odpowiedzialności odszkodowawczej, dotyczące obydwu reżimów, do których należą: powstanie szkody, zdarzenie, które ją wywołało, oraz wystąpienie związku przyczynowego pomiędzy tym zdarzeniem a szkodą. Odpowiedzialność odszkodowawcza aktualizuje się w przypadku wystąpienia szkody, wspólnota mieszkaniowa musi więc wykazać, że wskutek działania lub zaniechania członka zarządu poniosła określoną szkodę.

Szkoda co do zasady musi mieć charakter majątkowy, a więc polegać na doznaniu uszczerbku o charakterze materialnym przez wspólnotę mieszkaniową. Jako przykład takich działań należy wskazać zawarcie przez członka zarządu (lub członków) umowy o świadczenie usług na rzecz wspólnoty z przekroczeniem prze- 
widzianych w planie finansowym środków na ten cel w sytuacji, w której możliwe było zawarcie umowy $z$ konkurencyjnym podmiotem przy zastosowaniu niższych stawek. Szkoda może zostać wywołana wskutek zaniechania, w sytuacji gdy zarząd wspólnoty nie dochodzi od dłużnika należnych wspólnocie wierzytelności, doprowadzając do przedawnienia roszczenia. W tej sytuacji suma przedawnionej wierzytelności stanowi uszczerbek, jakiego doznała wspólnota - o ile wykaże, że gdyby uzyskano tytuł wykonawczy, to dobrowolnie lub w drodze egzekucji doszłoby do jej zaspokojenia. Wśród innych przypadków działania członka zarządu na szkodę wspólnoty mieszkaniowej należy wymienić niewykonywanie uchwał podjętych przez wspólnotę, działanie wbrew woli wspólnoty wyrażonej w uchwale, dokonywanie czynności z przekroczeniem zakresu kompetencji zarządu, tj. wykonywanie przez zarząd czynności przekraczających zakres zwykłego zarządu bez uchwały właścicieli lokali. Każdorazowo działanie takie musi wywołać szkodę, aby mogło stać się podstawą dochodzenia roszczeń odszkodowawczych wobec członka zarządu.

Przepisy kodeksu cywilnego identyfikują również szkodę niemajątkową (krzywdę), dotyczy ona jednak co do zasady osób fizycznych. W odniesieniu do wspólnoty mieszkaniowej nie można wykluczyć wystąpienia uszczerbku niemajątkowego wskutek naruszenia jej dobrego imienia jako ułomnej osoby prawnej. Zgodnie $z$ art. 43 k.c. dobra osobiste osób prawnych podlegają ochronie prawnej, a przepis ten za sprawą art. 331 k.c. znajduje zastosowanie do ułomnych osób prawnych, a więc także do wspólnot mieszkaniowych. Pod pojęciem dobrego imienia wspólnoty mieszkaniowej należy rozumieć jej renomę jako zbiorowości właścicieli danej nieruchomości, rozumianą jako ogół pozytywnych wyobrażeń i ocen właścicieli lokali oraz potencjalnych nabywców tych lokali ${ }^{25}$. Dobre imię wspólnoty mieszkaniowej mogą więc naruszać wypowiedzi, które obiektywnie oceniając, przypisują temu podmiotowi jako ogółowi właścicieli niewłaściwe postępowanie mogące spowodować utratę do niej zaufania potrzebnego do jej prawidłowego funkcjonowania, negatywną ocenę

25 Por. wyrok SA w Warszawie z 18 maja 2017 r., I ACa 380/16, Lex nr 2402412. 
danej nieruchomości oraz wspólnoty właścicieli, co w szczególności może skutkować spadkiem wartości lokali.

Między zdarzeniem, z którym ustawa łączy obowiązek odszkodowawczy, a szkodą musi istnieć związek przyczynowy. W prawie polskim przyjęto koncepcję adekwatnego związku przyczynowego, a więc odpowiedzialność obejmuje normalne następstwa zdarzenia, które szkodę spowodowało, co dotyczy obydwu reżimów odpowiedzialności cywilnoprawnej.

\subsection{Miernik staranności członka zarządu wspólnoty mieszkaniowej}

Członek zarządu wspólnoty mieszkaniowej ma obowiązek działać z należytą starannością w interesie wspólnoty mieszkaniowej, przy czym nie stosuje się do niego kryterium podwyższonej staranności, o której mowa w art. $355 \S 2$ k.c., o ile nie jest on profesjonalnym zarządcą. Tylko w przypadku, gdy członkiem zarządu wspólnoty zostaje licencjonowany zarządca nieruchomości, do jego osoby należy odnosić podwyższony miernik staranności wynikający z zawodowego charakteru.

Ustawa nie wymaga od członka zarządu spełniania jakichkolwiek wymogów, posiadania kwalifikacji lub doświadczenia. W związku z tym osoba taka ponosi odpowiedzialność jedynie za niezachowanie zwykłej, należytej staranności, choćby osoba ta, ze względu na swoje kwalifikacje i doświadczenie, nie była predysponowana do pełnienia funkcji członka zarządu. Jak wskazał Sąd Najwyższy, ocena miernika postępowania, którego istota tkwi w zaniechaniu dołożenia staranności, nie może być formułowana na poziomie obowiązków niedających się wyegzekwować, oderwanych od doświadczeń uwzględniających reguły zawodowe i konkretne okoliczności, a także określony typ stosunków ${ }^{26}$.

Jeśli członkiem zarządu zostaje osoba fizyczna nieposiadająca uprawnień zarządcy nieruchomości, nie można stosować do niej podwyższonego miernika staranności, jak w przypadku profesjonali-

${ }^{26}$ Wyrok SN z dnia 8 lipca 1998 r., III CKN 574/97, Lex nr 462941. 
sty. Należy jednak wymagać od takiej osoby podstawowej znajomości przepisów ustawy o własności lokali, w szczególności wiedzy o tym, jakie czynności zarząd może podjąć samodzielnie, a które wymagają uchwały ogółu właścicieli lokali. Należy założyć, że przyjęcie na siebie obowiązków członka zarządu wiąże się z koniecznością posiadania wiedzy o charakterze i zakresie tych obowiązków. Chodzi tu o wiedzę ogólną, dostępną dla laika, o podstawowe zasady funkcjonowania wspólnoty mieszkaniowej oraz jej zarządu - należy podkreślić, że od członka zarządu nie wymaga się pogłębionej wiedzy prawnej ani ekonomicznej.

Uwagi dotyczące miernika staranności odnoszą się do obydwu podstaw odpowiedzialności członka zarządu wspólnoty mieszkaniowej.

\section{Porównanie regulacji wybranych aktów prawnych}

W kodeksie spółek handlowych oraz w prawie spółdzielczym ${ }^{27}$ ustawodawca przewidział regulację wprost odnoszącą się do odpowiedzialności członka zarządu za szkodę wyrządzoną spółce lub spółdzielni. Zgodnie $z$ przepisami art. $293 \S 1$ k.s.h. oraz art. 483 $\S 1$ k.s.h. członek zarządu (a także członek rady nadzorczej, komisji rewizyjnej oraz likwidator) odpowiada wobec spółki za szkodę wyrządzoną działaniem lub zaniechaniem sprzecznym $z$ prawem lub postanowieniami umowy spółki, chyba że nie ponosi winy. Dodatkowo w $\S 2$ tych przepisów ustawodawca nakłada na te osoby podwyższony miernik staranności wynikający $z$ zawodowego charakteru działalności. Większość przedstawicieli doktryny przyjmuje, że jest to odpowiedzialność kontraktowa, a więc odpowiedzialność za nienależyte wykonywanie obowiązków wynikających z powołania do pełnienia funkcji członka zarządu ${ }^{28}$.

27 Ustawa $z$ dnia 16 września 1982 r. - Prawo spółdzielcze (tekst jednolity: Dz.U. z 2017 r. poz. 1560, dalej: pr. spółdz.).

28 A. Rachwał, op.cit., s. 1027; K. Strzelczyk, w: J.P. Naworski, K. Strzelczyk, T. Siemiątkowski, R. Potrzeszcz, Komentarz do Kodeksu spółek handlowych, 
W doktrynie prawa handlowego wskazano, że niewykonanie lub nienależyte wykonanie zobowiązania musi łączyć się z naruszeniem przepisów obowiązującego prawa lub postanowień umowy spółki ${ }^{29}$. W orzecznictwie uznano, że jeżeli niewykonana przez członka organu uchwała lub decyzja została wydana bez upoważnienia wynikającego $\mathrm{z}$ przepisów obowiązującego prawa lub postanowień umowy spółki, niezastosowanie się do niej nie może uzasadniać odpowiedzialności na podstawie art. 293 k.s.h. ${ }^{30} \mathrm{~W}$ konsekwencji niezastosowanie się członka zarządu do uchwał i decyzji poszczególnych organów spółki może uzasadniać odpowiedzialność na podstawie art. 293 k.s.h. tylko o tyle, o ile uchwały i decyzje mają umocowanie $\mathrm{w}$ przepisach obowiązującego prawa lub $\mathrm{w}$ umowie spółki. Powyższy pogląd w całości należy odnieść do odpowiedzialności członka zarządu wspólnoty mieszkaniowej w razie niewykonania uchwały sprzecznej $z$ prawem lub podjętej $z$ naruszeniem zasad prawidłowego gospodarowania nieruchomością wspólną.

W prawie spółdzielczym została przewidziana regulacja wzorowana $^{31}$ na rozwiązaniu przyjętym w k.s.h. - zgodnie $z$ przepisem art. 58 pr.spółdz. członek zarządu (a także członek rady oraz likwidator) odpowiada wobec spółdzielni za szkodę wyrządzoną działaniem lub zaniechaniem sprzecznym $z$ prawem lub postanowieniami statutu spółdzielni, chyba że nie ponosi winy. Przewidziana w tej regulacji odpowiedzialność odszkodowawcza członka zarządu spółdzielni oparta jest na zasadzie winy, przy czym konstrukcja przepisu wskazuje na domniemanie winy. Jak wyjaśnił Sąd Naj-

Spółka z ograniczona odpowiedzialnościa, Warszawa 2001, s. 626; K. Bilewska, Dochodzenie roszczeń spółki kapitałowej przez jej wspólników, Warszawa 2008, s. 142.

29 A. Kidyba, Kodeks spótek handlowych. Komentarz, Warszawa 2011, s. 1327.

30 Wyrok SA w Szczecinie $z$ dnia 30 marca 2015 r., I ACa 825/14, Lex nr 1782072.

${ }^{31}$ Przepis art. 58 został zmieniony przez art. 3 pkt 10 Ustawy z dnia 3 czerwca 2005 r. o zmianie ustawy o spółdzielniach mieszkaniowych oraz niektórych innych ustaw (Dz.U. z 2005 r. Nr 122, poz. 1024) z dniem 22 lipca 2005 r. 
wyższy, odpowiedzialność członka zarządu na podstawie art. 58 pr.spółdz. jest cywilną odpowiedzialnością odszkodowawczą, co oznacza, że w zakresie nieuregulowanym w tym przepisie do tej odpowiedzialności zastosowanie mają zasady ogólne. Oznacza to, że poszkodowany musi wykazać dowód nie tylko powstania szkody, ale i jej wysokości, oraz dowód związku przyczynowego pomiędzy szkodzącym, sprzecznym z prawem lub statutem zachowaniem członka zarządu a powstałą szkodą; odpowiedzialność ta oparta jest na domniemaniu winy pozwanego ${ }^{32}$.

W związku z konstrukcją tych przepisów na członku zarządu spółki lub spółdzielni spoczywa ciężar udowodnienia braku winy, czyli dołożenia należytej staranności przy wykonywaniu swych obowiązków ${ }^{33}$. Uzasadnieniem dla tak surowej regulacji jest argument oparty na szerokich kompetencjach członków zarządu spółek, jako osób prawnych funkcjonujących w różnych płaszczyznach ${ }^{34}$. Takiego przepisu, ustanawiającego podstawę prawną odpowiedzialności członka zarządu za szkody, nie ma w ustawie o własności lokali, co skutkuje koniecznością stosowania regulacji ogólnych. W konsekwencji dochodzenie roszczeń odszkodowawczych przeciwko członkowi zarządu wspólnoty mieszkaniowej może być trudniejsze, niż w przypadku członka zarządu spółki lub spółdzielni. Specjalna regulacja zawarta w k.s.h. oraz pr.spółdz. konkretyzuje przesłanki odpowiedzialności członków organów tych osób prawnych, oraz przede wszystkim nie pozostawia żadnych wątpliwości co do samej konstrukcji odpowiedzialności za szkody wyrządzone spółce lub spółdzielni. W tym kontekście, jak słusznie wskazano w piśmiennictwie, rozważania o kontraktowym lub deliktowym charakterze odpowiedzialności piastuna organu spółki mają wyłącznie wymiar teoretyczny ${ }^{35}$.

${ }^{32}$ Wyrok SN z dnia 20 czerwca 2013 r., V CSK 730/12, Lex nr 1396454.

${ }^{33}$ Wyrok SN z dnia 24 czerwca 2015 r., II CSK 554/14, Lex nr 1767100.

${ }^{34}$ A. Koch, Zasady i przesłanki odpowiedzialności za szkody wyrządzone spótce z ograniczona odpowiedzialnościa - na tle przepisów kodeksu spółek handlowych, w: Odpowiedzialność cywilna. Księga pamiatkowa ku czci Profesora Adama Szpunara, Kraków 2004, s. 539.

35 Ibidem. 
Regulacja przewidziana dla spółek oraz spółdzielni jest więc korzystniejsza dla tych podmiotów niż ta, która dotyczy wspólnot mieszkaniowych. Podstawy odpowiedzialności odszkodowawczej członka zarządu spółki lub spółdzielni oraz jej zasady są jednoznacznie sformułowane $\mathrm{w}$ odrębnym przepisie. W przypadku wspólnoty mieszkaniowej brak takiej regulacji skłaniać może do odrzucania reżimu kontraktowego jako nieznajdującego w ogóle zastosowania $\mathrm{w}$ sytuacji niezawarcia $z$ piastunem organu odrębnej umowy, co jednak uznać należy za stanowisko błędne ze względu na cywilnoprawny charakter stosunku organizacyjnego.

Należy zwrócić uwagę na brak w przepisach k.s.h. oraz pr.spółdz. szczególnych wymogów w odniesieniu do kwalifikacji członków zarządu spółek i spółdzielni, podobnie jak w przypadku wspólnot mieszkaniowych. Niezależnie od tego zagadnienie odpowiedzialności odszkodowawczej członka zarządu zostało wyraźnie uregulowane w odniesieniu do tych podmiotów prawa, w przypadku zaś wspólnoty mieszkaniowej zostało pominięte. Uzasadnienia dla takiego rozwiązania można poszukiwać w charakterze spółek i spółdzielni jako przedsiębiorców oraz rodzaju prowadzonej przez nie działalności. Jednakże $z$ tego powodu dla członka zarządu spółki kapitałowej ustawodawca przewidział podwyższony miernik staranności, właściwy profesjonaliście. Wspólnoty mieszkaniowe zostały ustawowo powołane do sprawowania zarządu nieruchomością wspólną, nie są one przedsiębiorcami. $Z$ jednej strony prowadzenie spraw takiego podmiotu jest zatem zdecydowanie mniej skomplikowane niż prowadzenie spraw spółki kapitałowej czy spółdzielni. $Z$ drugiej jednak chodzi o zarządzanie majątkiem wspólnym właścicieli lokali oraz interesami wspólnoty mieszkaniowej, a więc podejmowanie czynności faktycznych i prawnych w odniesieniu do cudzego majątku. W razie niewłaściwego wykonywania czynności zarządu wspólnota może ponieść szkodę, podobnie jak spółka handlowa czy spółdzielnia; ustawy nie wiążą charakteru odpowiedzialności z rozmiarem wyrządzonej szkody. Majątek wspólnoty mieszkaniowej oraz szeroko rozumiany interes ekonomiczny właścicieli lokali zasługuje na ochronę, tak samo jak majątek spółek i spółdzielni oraz interes ekonomiczny ich wspólników. Przemawia to za surowszą regulacją odpowiedzialności za szkody wyrządzone wspólnocie przy 
wykonywaniu czynności członka zarządu, a więc za wprowadzeniem wyraźnej regulacji tej odpowiedzialności w przepisach ustawy o własności lokali, na wzór art. 58 pr.spółdz.

\section{Podsumowanie}

Przepisy ustawy o własności lokali nie zawierają szczególnej regulacji odnoszącej się do odpowiedzialności odszkodowawczej członków zarządu wspólnoty mieszkaniowej. Nie można jednak wykluczyć wyrządzenia wspólnocie mieszkaniowej szkody w związku ze sprawowaniem funkcji członka zarządu. Zgodnie $z$ regulacją art. 1 ust. 2 u.w.1. w takim przypadku zastosowanie znajdą przepisy kodeksu cywilnego, regulujące podstawy i przesłanki odpowiedzialności odszkodowawczej.

Jeśli szkoda zostanie wyrządzona wskutek niewykonania lub nienależytego wykonania obowiązków wynikających $z$ ustawy lub uchwał podjętych przez właścicieli lokali, członek zarządu poniesie odpowiedzialność kontraktową na podstawie art. 471 k.c., a w razie wyrządzenia szkody czynem niedozwolonym członek zarządu będzie ponosił odpowiedzialność na podstawie art. 415 k.c. Zasadne wydaje się wprowadzenie do ustawy o własności lokali regulacji wzorowanej na przepisie art. 58 pr.spółdz., dla wzmocnienia pozycji wspólnoty mieszkaniowej w przypadku wyrządzenia jej szkody wskutek działań lub zaniechań członka zarządu.

\section{STRESZCZENIE}

Odpowiedzialność odszkodowawcza członka zarządu wspólnoty mieszkaniowej

Przepisy ustawy o własności lokali nie zawierają szczególnej regulacji odnoszącej się do odpowiedzialności odszkodowawczej członków zarządu wspólnoty mieszkaniowej. W tej sytuacji do odpowiedzialności członka zarządu za szkody wyrządzone wspólnocie stosuje się przepisy ogólne kodeksu cywilnego, a więc dotyczące odpowiedzialności deliktowej oraz odpowiedzialności kontraktowej. Przepisy kodeksu spółek handlowych 
oraz prawa spółdzielczego zawierają odrębną regulację poświęconą zasadom odpowiedzialności członków zarządu spółek oraz spółdzielni za szkody wyrządzone w związku ze sprawowaniem tej funkcji, która ułatwia wystąpienie z roszczeniem odszkodowawczym wobec członka zarządu.

Słowa kluczowe: wspólnota mieszkaniowa; zarząd wspólnoty; członek zarządu wspólnoty; odpowiedzialność członka zarządu wspólnoty mieszkaniowej

\section{SUMMARY}

\section{Liability for damages of a board member of a housing community}

The provisions of the Act of Ownership of Premises do not contain any special regulation regarding the liability for damages of board members of a housing community. In this situation, the general provisions of the Civil Code, that is the provisions concerning liability in tort and contractual liability, apply to the liability of a member of the management board for damage caused to the community. The provisions of the Code of Commercial Companies and Partnerships, and the provisions of Cooperative Law contain a separate regulation on the principles of liability of members of the management board of companies and cooperatives for damage caused in connection with the exercise of this role, which facilitates the laying of a claim for damages against a member of the management board.

Key words: ownership of premises; liability for damages; board member of a housing community

\section{BIBLIOGRAFIA}

Banaszczyk Z., w: System Prawa Prywatnego, t. I, red. M. Safjan, Warszawa 2012.

Bilewska K., Dochodzenie roszczeń spółki kapitałowej przez jej wspólników, Warszawa 2008.

Dadańska K.A., Działanie osoby prawnej, Warszawa 2006.

Dziczek R., Własność lokali. Komentarz. Wzory pozwów i wniosków, Warszawa 2012.

Ignatowicz J., Komentarz do ustawy o wtasności lokali, Warszawa 1995.

Kaliński M., Szkoda na mieniu i jej naprawienie, Warszawa 2011. 
Kidyba A., Kodeks spółek handlowych. Komentarz, Warszawa 2011.

Koch A., Zasady i przesłanki odpowiedzialności za szkody wyrzadzone spótce z ograniczoną odpowiedzialnościa - na tle przepisów kodeksu spótek handlowych, w: Odpowiedzialność cywilna. Księga pamiątkowa ku czci Profesora Adama Szpunara, red. M. Pyziak-Szafnicka, Kraków 2004.

Kozińska J., Status prawny zarządu wspólnoty mieszkaniowej - zagadnienia wybrane, „Rejent” 2003, nr 12.

Kozińska J., Środki kontroli działalności zarzadu lub zarządcy według ustawy o własności lokali, „Studia Prawnicze” 2013, nr 2(57).

J. P. Naworski, K. Strzelczyk, T. Siemiatkowski, R. Potrzeszcz, Komentarz do kodeksu spótek handlowych. Spółka z ograniczona odpowiedzialnościa, Warszawa 2001.

Pisuliński J., w: System Prawa Prywatnego, t. 3: Prawo rzeczowe, red. Z. Radwański, Warszawa 2013.

Rachwał A., w: System Prawa Handlowego. Prawo Spótek Handlowych, red. S. Włodyka, Warszawa 2007.

Radwański Z., Olejniczak A., Zobowiązania - część ogólna, Warszawa 2016.

Sikorska-Lewandowska A., Charakter prawny uchwał właścicieli lokali, „Przegląd Sądowy” 2014, nr 6.

Sikorska-Lewandowska A., Uchwały wtaścicieli lokali. Studium prawne, Warszawa 2017.

Skibiński P., Reprezentacja wspólnoty mieszkaniowej na gruncie ustawy o wtasności lokali, „Przegląd Sądowy” 2007, nr 5.

Strzelczyk R., Turlej A., Własność lokali. Komentarz, Warszawa 2015.

Szewczyk M., Reprezentacja wspólnoty mieszkaniowej, „Radca Prawny” $2001, \mathrm{nr} 1$.

Szumański A. w: System Prawa Prywatnego, t. 17A: Prawo Spółek Kapitałowych, red. S. Sołtysiński, Warszawa 2015.

Szymczak I., Wspólnota mieszkaniowa, Warszawa 2014. 